Short Communication

\title{
Differentiation between viral exanthema and allergic exanthema by IFN- $\gamma$ and IL-4 assay
}

\author{
Mokhtari Azad T. *, Mirzaie A., Rezaie F., Seadatmand Z., Salimi V., Hamkar R. \\ Dept. of Virology, School of Public Health and Institute of Health Research, Tehran University of Medical Sciences.
}

$\mathrm{M}$ acular and maculo-papular skin reactions are frequent events in viral infections as well as in allergies $(1,2,3)$. Their histology and clinical morphology is often similar and clinical diagnosis of rash is often difficult and misdiagnosis is not rare, specially in failure to detect virus specific antibodies of the IgM class $(4,5,6,7,8)$. Measles, rubella and parvovirus B19 are the most important childhood exanthematic disease, but some other viruses (enteroviruses, HHV-6, EBV ,etc) can cause exanthema(9) that diagnosis of each of them separately, requires spending lots of time and money. On the other hand, allergies are another important cause of exanthema and differentiation between viral exanthema and allergic exanthema can be difficult sometimes (10).

Studies on viral specific $\mathrm{T}$ cell lines have shown that these cells are frequently associated with elevated IFN- $\gamma$ levels at the early phase of disease $(8,11,12,13)$. More over allergic specific $\mathrm{T}$ cells represent a significant source of IL-4 $(8,14,15)$. In this study, we applied this hypothesis to demonstrate whether we can use IFN- $\gamma$ and IL-4 serum levels to differentiate between viral exanthema and allergic exanthema and if we can, how many of our negative measles, rubella and parvovirus B19 cases are associated with viral infections and how many of them are associated with allergies. Patients sera were taken from measles suspected cases (all patients presenting with rash, high fever, and at least one of the following symptoms: Cough, Coryza or Conjunctivitis) (16) by health care workers from the epidemiological surveillance in Iran. Sera were

\footnotetext{
*Corresponding author: Mokhtari Azad T. Tehran University of Medical Sciences.

Tel: + 982188082444, Fax: +982188962343

Email: Mokhtari@sina.tums.ac.ir
}

collected from 27 provinces of Iran in 2005 and sent to Department of Virology/School of Public Health and Institute of Health Research of Tehran University. With Each Samples, there was a questionnaire that included information such as age, sex, province and vaccination status. This sera were tested in terms of measles, rubella and B19 by ELISA and then A total of 88 negative measles, rubella and B19 cases were analyzed for serum IFN- $\gamma$ and IL- 4 by by a commercially available ELISA kits (were bought from Austrian Bender med system company). Among 88 cases for analyzing in terms of IFN- $\gamma$ and IL- 4 , in 30 cases only IFN- $\gamma$, in 25 cases only IL- 4 , in 3 cases both IFN $-\gamma$ and IL-4 and in 30 cases none of they were positive. IFN- $\gamma$ and IL-4 level in 22 normal sera were tested by producing company and in the most cases were lower than $8 \mathrm{pg} / \mathrm{ml}$. in all of our positive cases, this cytokine levels were upper than $8 \mathrm{pg} / \mathrm{ml}$. however among our positive IFN- $\gamma$ cases ,in only 10 sera ,IFN- $\gamma$ level was upper than 20 $\mathrm{pg} / \mathrm{ml}$ and also in only 17 cases of our IL-4 positive cases, IL-4 level was upper than $20 \mathrm{pg} / \mathrm{ml}$. assuming that IFN- $\gamma$ positive cases $(34 \%)$ are due to viruses and IL-4 positive cases $(28 \%)$ are due allergies, the cause of exanthema in $38 \%$ of cases was still unknown (Fig. 1).

It can be concluded that about 30 cases of negative measles, rubella and B19 cases in which the serum IFN- $\gamma$ level was higher than normal range are associated to viruses and about 25 cases of them in which IL-4 level was higher than normal range are associated to allergies. However, in 30cases none of these cytokine increased, which can be due to different factors such as the interval between rash occurrence and sampling time(other studies has shown that levels of these cytokine will decreased as time passes) $(8,11,12)$, freeze - thawed of sera and type of kits. In addition, in 3 cases both of these cytokine levels were higher than normal 


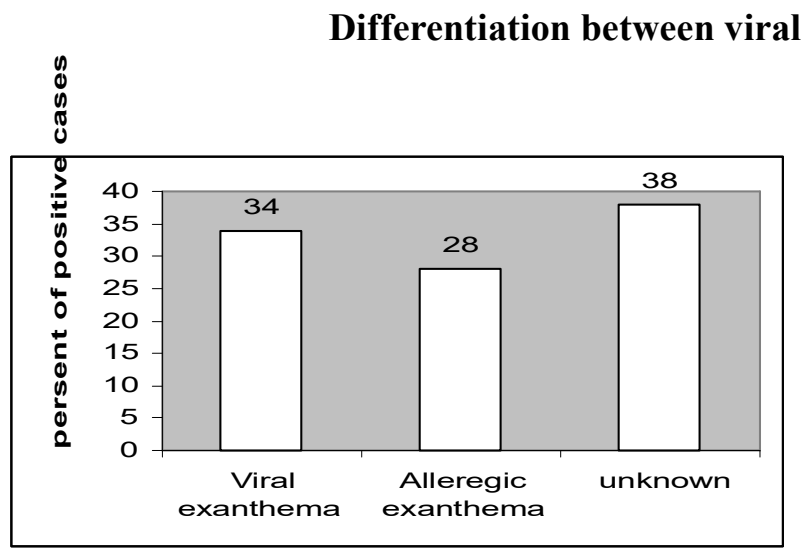

Fig. 1: Incidence of exanthema in the study population

range that can be due to factors as simultaneous occurrence of viral infections and allergies or allergy caused by the viruses (e.g. RSV). Consider resulting of this study, we can't say that using these two cytokines is effective for definite differentiating between viral and allergic exanthema and applying this hypothesis is related to careful studies and controlling all stages of the process, which includes sampling, maintaining the samples, performing the tests and analyzing the results in the future. However, clearly, using of serum cytokines is useful in differentiating viral exanthema from allergic exanthema in spite of the similar clinical picture.

\section{References}

1. Kimura, M., A. Yamaide, S. Tsuruta, I. Okafuji and T. Yoshida; 2002; Development of the capacity of peripheral blood mononuclear cells to produce IL-4, IL-5 and IFN-gamma upon stimulation with house dust mite in children with atopic dermatitis. Int. Arch. Allergy Immunol. 127: 191-197.

2. Huber, A. and B. Pfaeffle; 1994; Diffrential $\mathrm{Th}_{1}, \mathrm{Th}_{2}$ cell response in male and female BALB/C infected with Coxachie virus B type 3. J Virol. 68:5126-5132.

3. Naisbitt, D.; 2004; Drug hypersensitivity reactions in skin: understanding mechanisms and the development of diagnostic and predictive tests. Toxicology 194:179-196.

4. Naisbitt, D. J., M. Britschgi, G. Wong, J. Farrell, J. P. H. Depta, D. W. Chadwick, W. J. Pichler, M. Pirmohamed, and B. K. Park; 2003; Hypersensitivity Reactions to Carbamazepine: Characterization of the Specificity, Phenotype, and Cytokine Profile of Drug-Specific T Cell Clones. Molecular Pharmacology 63:732-774.

5. Hayley, A. G., Y. Maldonado, L. L. Yasukawa, J. Beeler, S. Audet, M. M. Rinki, R. DeHovitz and A. M. Arvin; 1999; IL-12, IFN- $\gamma$, and $\mathrm{T}$ cell proliferation to Measles in Immunized infants. The Journal of Immunology 162:5569-5575.

6. Smart, J., E. Horak, A. Kemp, C. Robertson and M. Tang; 2002; Polyclonal and allergeninduced cytokine responses in adults with asthma. Resolution of asthma is associated with normalization of IFN- gamma responses. J. Allergy Clin. Immunol 110: 450-6.

7. Smart, J. M. and A. S. Kemp; 2002; Increased Th1 and Th2 allergen-induced cytokine responses in children with atopic disease Clin. Exp. Allergy 32:796-802.

8. Hari, Y., A. Urwyler, M. Hurni, N. Yawalkar, C. Dahinden, T. Wendland, L. R. Braathen, L. Matter and W. J. Pichler; 1999; Distinct serum cytokine levels in Drug and measles induced exanthemas. Int Arch Allergy immunol 120(3) :225-229.

9. Siegrist, C. A., F. Saddallah, C. Tougne, X. Martinez, J. Kovarik and P. H. Lambert; 1998; Indication of neonatal TH1 and CTL response by live viral vaccines. A role for replication patterns within antigen presenting cell. Vaccine 16:1473-1478.

10. Yokota, S., T. Okabayashi, N. Yokosawa and N. Fujii; 2004; Growth arrest of epithelial cells during measles virus infection is caused by regulation of interferon regulatory factor 1 . Journal of Virology 78(9):4591-4598.

11. Mossman, K. L., R. F. Macgregor, J. J. Rozmus, A. B. Goryachev, A. M. Edwards and J. R. Smiley; 2001; Herpes simplex virus triggers and then disarms a host antiviral response. J. Virol 75: 750-758.

12. Pichler, W. J., M. Zanni, S. VonGreyerz, B. Sclunyder, D. Mauri-Hellweg and T. Wendland; 1997; High IL-5 Production by human drug-specific $\mathrm{T}$ cell clones. Int Allergy immunol 113:177-180.

13. Ohga, S., C. Miyazaki, K. Okada, K. Akazawa and K. Ueda; 1992; The inflammatory cytokines in measles. Correlation between serum interferon- $\gamma$ levels and lymphocyte sub populations. Eur J Pediatr 151:492. 
14. Gale, M. J., C. M. Blakely, B. Kwieciszewski, S. Lai, M. Dossettt, N. M. Tang,Marcus, J. Korth, S. J. Polyak, D. R. Gretch and M. G. Katze; 1998; Control of PKR protein kinase by hepatitis $\mathrm{C}$ virus $5 \mathrm{~A}$ nonstructural protein: molecular mechanisms of kinase regulation. Mol. Cell. Biol. 18:5208-5218.

15. Samuel, C. E.; 2001; Antiviral actions of interferons. Clin. Microbiol. Rev. 14: 778 809.

16. Doly, J., A. Civas, S. Navarro and G. Uze; 1998; Type I interferons: expression and signalization. Cell Mol Life Sci. 54(10):11091121. 